\title{
Strategi Komunikasi Dalam Kesantunan Berbahasa Komunitas Antarsantri Pondok Pesantren Al-Hikmah Sukoharjo
}

\author{
Elen Inderasari, Ferdian Achsani, Hilmy Mahya Masyhuda \\ Institut Agama Islam Negeri Surakarta \\ inderasari85iain@gmail.com
}

Diterima 9 Agustus 2018/Disetujui 10 Agustus 2018

\begin{abstract}
Abstra
Communication is one of the most important aspects of human life. Communication strategies are important to facilitate the achievement of the objectives and purpose of language speech. The use of language becomes the most important tool in communication must pay attention to the rules of language politeness. The purpose of this study is to describe various communication strategies in the form of language politeness that occur in the Islamic boarding school community. This research method uses qualitative method because the data is descriptive. Researchers plunged into the field to observe, researchers were students from the Al-Hikmah Islamic boarding school. In collecting data, the researcher uses the technique to see, involve, be competent, record, and record. There are three types of methods in the research stage, namely (1) data collection methods, (2) data analysis methods, and (3) methods for presenting the results of data analysis. Data analysis techniques in this study were carried out in a descriptive qualitative manner with the following steps: (1) collecting verbal data in the form of conversation or dialogue and nonverbal data; (2) record, collect, and select data that has been collected; (3) transcribe data that has been collected; (4) translating findings in regional languages; (5) perform the description and data analysis, and (6) summarize the results of the analysis. Communication strategy in communitylanguage politeness among students of Al-Hikmah Sukoharjo Islamic Boarding School is not influenced by cultural differences. Cultural culture is not one of the factors causing irregularities in the principle of politeness. there is a politeness in which contains the maxim of wisdom, maxim of generosity, maxim of appreciation, maxim of appreciation, maxim of greed, maxim of agreement, and maxim of sympathy in communication speech acts. This happens because they respect each other's cultural culture, both the culture of East Java culture and the culture of Central Java.
\end{abstract}

Keyword: communication strategy, politeness principle, santri community

\section{Pendahuluan}

Bahasa merupakan sarana yang digunakan manusia untuk berkomunikasi dengan sesamanya. Melalui bahasa, manusia saling berinteraksi, mengutarakan pendapat, perasaan, ungkapan emosi seseeorang, dan berosialisasi. Kridalaksana (dalam Chaer, 2012:32) mengemukakan bahwa bahasa merupakan sistem lambang bunyi yang arbiter yang digunakan oleh anggota kelompok social untuk bekerja sama, berkomunikasi, dan mengidentifikasi diri. 
Dengan demikian, keberadaan bahasa telah mempermudah manusia dalam berinteraksi dan berkomunikasi.

Dalam berkomunikasi, sering seseorang berkata atau mengungkapkan sesuatu hal yang dapat melukai perasaan lawan tutur. Saat ini banyak ditemukan di kalangan remaja bahwa ketika mereka berbicara kepada orang lain, akibat dari bahasa yang digunakan kurang diperhatikan. Hal itu di sebabkan oleh pengabaian prinsip kesantunan dalam berbahasa. Menurut Fithri (2017) pengemasan tuturan kebahasaan yang lebih baik akan menghasilkan bahasa yang santun dan sopan; dan sebaliknya, pengemasan bahasa yang kurang baik akan menjadikan bahasa itu kurang sopan dan santun pula. Menurut Sutrisni (2005:1), suatu tuturan dalam interaksi sosial yang bersifat jelas dan tidak ambigu merupakan langkah yang harus dilakukan oleh peserta tutur agar komunikasi dapat berjalan dengan baik. Karena itu, dalam berinteraksi sosial dan berkomunikasi, baik penutur maupun mitra tutur perlu memperhatikan kaidah-kaidah kebahasaan.

Penggunaan prinsip kesantunan dalam berkomunaksi perlu dilakukan oleh pelibat tutur dengan harapan agar makna tuturan dipahami dengan baik dan tidak melukai perasaan penutur dan lawan tutur. Menurut Rahardi (2005), kesantunan berbahasa dapat dilihat melalui pemilihan kata (diksi) sampai dengan penyusunan kalimat, tata bahasa, pilihan ragam, serta penggunaan tempo dan intonasi. Salah satu strategi penggunaan kesantunan berbahasa dalam berkomunikasi dapat dilakukan dengan saling menghargai dan menghormati antara penutur dan lawan tutur (Susilaningtyas, Wibisono, dan Suyanto, 2017). Dewasa ini dalam aktivitas komunikasi di berbagai tempat dan situasi sering ditemukan adanya penyimpanganpenyimpangan kaidah kesantunan berbahasa. Salah satu faktor yang berpengaruh terhadap terjadinya penyimpangan tersebut adalah adanya keragaman sosial budaya penuturnya. Karena itu, dalam tindak komunikasi harus memperhatikan norma-norma budaya, sehingga menghasilkan kesantunan berbahasa (Rahayu, 2013).

Pondok Pesantren Al-Hikmah Sukoharjo merupakan salah satu pondok pesantren yang mayoritas santrinya berasal dari Jawa Timur dan Jawa Tengah. Sebagaimana telah kita ketahui bahwa masyarakat Jawa Timur dikenal dengan penggunaan bahasa yang lebih kasar ketika mereka berinteraksi dengan mitra tutur dalam suasana keakraban, sedangkan masyarakat Jawa Tengah terkenal dengan penggunaan bahasa dengan intonasi lebih halus dan menerapkan tingkat tutur bahasa Jawa. Meskipun demikian, interaksi antarsantri di pondok pesantren ini bersifat saling menghormati dan menghargai sehingga terjalin kesantunan dalam berkomunikasi. 
Faktor sosial budaya, khususnya prinsip kerja sama dan prinsip kesantunan, sangat memengaruhi pilihan bentuk ekspresi penerimaan yang digunakan dalam sebuah percakapan. Ekspresi penerimaan tersebut juga sangat memengaruhi prospek hubungan interpersonal antarpartisipan interaksi karena berpotensi memengaruhi kondisi "muka" para partisipan percakapan. Tindak penyelamatan "muka" yang merupakan tindakan kesopanan akan cenderung menunjukkan rasa hormat dan kesetiakawanan (Yule, 2014:105).

Hasil penelitian yang dilakukan di SD Immersion Ponorogo menyimpulkan bahwa dalam interaksi sosial di sekolah, guru menerapkan prinsip kesantuan yang bertujuan untuk membangkitkan motivasi siswa. Selain itu, ditemukan juga adanya pelanggaran terhadap prinsip kesantunan. Pelanggaran prinsip kesantunan terjadi karena guru ingin memberikan pembelajaran kepada siswa yang tidak memperhatikan apa yang disampaikan oleh guru (Setiawan dan Rois, 2017). Penelitian ini menggunakan pendekatan pragmatik dengan mengkaji penerapan prinsip kesantunan dalam interaksi kebahasaan di Pondok Pesantren AlHikmah Sukoharjo.

Dalam kajian pragmatik prinsip kesantunan terdiri atas enam maksim, yaitu maksim kebijaksanaan, maksim kedermawanan, maksim penghargaan, maksim kesederhanaan, maksim pemufakatan, dan maksim kesimpatian (Yule, 2014). Maksim-maksim tersebut Dengan adanya prinsip-prinsip kesantunan diharapkan para penutur mampu menggunakan bahasa dengan santun. Kesantunan harus dijunjung tinggi dengan memperhatikan aspek-aspek sosial budaya, agar di antara para penutur tidak ada kesalahpahaman yang dapat menimbulkan perselisihan ketika berinteraksi sosial.

\section{Metode Penelitian}

Penelitian ini menggunakan metode kualitatif karena data bersifat deskriptif. Data yang terkumpul berbentuk kata-kata sehingga tidak menekankan pada angka. Peneliti terjun ke lapangan untuk melakukan observasi. Dalam kegiatan pengumpulan data, peneliti menggunakan teknik simak, libat, cakap, rekam, dan catat. Objek penelitian adalah santri Pondok Pesantren Al-Hikmah. Dalam kegiatan pengumpulan data, peneliti merekam setiap percakapan yang dilakukan oleh santri. Jumlah santri yang diamati tidak dibatasi, sehingga hal tersebut mempermudah peneliti untuk memperoleh data sesuai kebutuhan. Perekaman dilakukan dengan teknik sadap karena pada hakikatnya penyimakan diwujudkan dengan penyadapan (Sudaryanto, 1993:133). Setelah rekaman data terkumpul, peneliti menyimak hasil rekaman tersebut untuk mengambil data-data yang diperlukan. Kemudian peneliti 
menyimpulkan data yang diperoleh. Hal tersebut sesuai dengan tiga tahapan penelitian yang dilakukan, yaitu (1) pengumpulan data, (2) analisis data, dan (3) penyajian hasil analisis data. Teknik analisis data dalam penelitian ini dilaksanakan secara deskriptif kualitatif dengan langkah-langkah sebagai berikut: (1) mengumpulkan data verbal berupa percakapan atau dialog dan data nonverbal; (2) mencatat, menghimpun, dan menyeleksi data-data yang telah dikumpulkan; (3) mentranskrip data-data yang telah dikumpulkan; (4) menerjemahkan temuan yang berbahasa daerah; (5) melakukan deskripsi dan analisis data, serta (6) menyimpulkan hasil analisis.

\section{Hasil Dan Pembahasan}

Keenam maksim sebagai jabaran dari prinsip kesantunan akan dibahas berdasarkan data di bawah ini.

\subsection{Maksim Kebijaksanaan}

Maksim kebijaksaan terdapat pada percakapan antara Fajar dan Aris ketika setelah adzan Duhur. Fajar melihat peci yang digunakan Aris mulai berwarna kemerah-merahan yang menandakan sudah waktunya untuk membeli peci yang baru. Berikut bentuk tuturannya:

(1) Fajar : Ehh Ris, awakmu ngerti ta nggon biasane dewe tuku kitab?

(Ehh..Ris. kamu tau kan? tempat biasa kita membeli kitab?)

(2) Aris : Iyo ngertilah, nang pojok klewer kae to? (Iya tahulah, di pojok klewer itu kan?)

(3) Fajar : "Saiki nang kono enek sorban, sajadah kro kupluk barang e, komplit pokoke." (Sekarang disana menjual sorban, sajadah, peci, lengkap pokoknya.)

Percakapan antara santri yang bernama Aris dan Fajar terjadi pada siang hari. Fajar memberikan informasi tentang toko langganan mereka yang menjual berbagai peralatan salat. Penggunaan maksim kebjaksanaan terdapat pada tuturan ketiga yang disampaikan oleh Fajar. Fajar memaksimalkan keuntungan temannya dengan memberikan informasi mengenai barang yang dijual di toko langganan mereka. Informasi tersebut tidak merugikan kedua pihak penutur.

Maksim kebijaksanaan juga terdapat dalam percakapan antara Fata dan Arvan. Fata kebingungan dengan bolpoinnya yang sering mati saat digunakan untuk mengaji pada malam hari. Berikut bentuk tuturannya.

(1) Fata: Bro, polpenku angger dingo ngaji mesti mati e.

(Bro, bolpoinku kalau di pakai untuk ngaji pasti mati.)

(2) Arvan : Jajal nggon pucuk e polpen kui di bong.

(Coba ujung bolpoinnya dibakar.)

(3) Fata: Halah, po ray o podo wae?

(Halah, bukannya sama saja?) 
(4) Arvan : Jajalen sek to, gak usah kawatir rusak.

(Dicoba dulu, jangan kawatir rusak.)

Maksim kebijaksanaan terdapat pada tuturan (4). Arvan memberi informasi cara memperbaiki bolpoin yang mati. Hal tersebut menguntungkan pihak Fata dan kedua pihak tidak ada yang merasa dirugikan. Contoh maksim kebijaksanaan yang lain juga terdapat pada percakapan Wahid dan Umam. Konteks tuturan terjadi ketika Umam merasa kepalanya pusing karena tidur tidak memakai bantal. Kemudian, Wahid menawarkan tidur di kamarnya dengan dipinjami bantal. Berikut bentuk tuturannya.

(1) Umam : Sirahku ngelu, mambengi turu ora bantalan.

(Kepalaku pusing, semalam tidur tidak memakai bantal.)

(2) Wahid : Mulane turu kamarku wae, tak jilehi bantal.

(Makanya tidur di kamarku, aku pinjami bantal.)

(3) Umam : Temenan kowe?

(Betul kami meminjami?)

(4) Wahid : Iyo, mulane moro o kamarku nek arek turu.

(Iya, makanya datang ke kamarku kalau mau tidur.)

Penggunaan maksim kebijaksanaan terdapat pada tuturan (2) yang mengandung informasi yang menguntungkan pihak Umam. Wahid memberi perintah yang menguntungkan Umam. Hal tersebut dilakukan agar Umam tidak merasa pusing saat tidur. Kedua pihak tidak ada yang merasa dirugikan dan tuturan di atas menunjukkan adanya saling memberi informasi secara bijak.

\subsection{Maksim Kedermawanan}

Maksim kedermawanan terdapat dalam percakapan Umam dan Anif ketika keduanya akan membeli kopi. Berikut bentuk tuturannya.

(1) Umam : Golek kopi ireng wae yo ben awet? Tak ngajak Wahid.

(Cari kopi hitam saja ya biar awet? Aku ajak Wahid.)

(2) Anif: Iyo wes. ndang budal kono, tak enteni kamar.

(Iya sudah, silahkan berangkat, aku tunggu di kamar.)

Maksim kedermawanan terdapat pada tuturan (1). Konteks tuturan terjadi ketika Umam menawarkan kopi yang akan mereka beli. Kemudian Umam mengajak Wahid agar Anif tidak merasa kerepotan, sehingga keuntungan besar didapatkan oleh Anif. Contoh maksim kedermawanan juga terdapat pada percakapan antara Fajar dan Anif. Keduanya sedang duduk santai di kamar kemudian Fajar berdiri hendak melangkah keluar kamar. Berikut bentuk tuturannya.

(1) Fajar: Kui sampahmu Nif? Gwo rene tak guake sisan.

(Itu sampah kamu Nif? Bawa sini aku buang.)

(2) Anif : Oh, ho.o bro, iki-iki.. 
(Oh, iya bro, ini-ini..)

Maksim kedermawanan terdapat pada data (1). Konteks tuturan terjadi ketika Fajar hendak pergi keluar kamar dan melihat ada sampah di samping tempat duduk Anif. Kemudian Fajar menawarkan diri untuk membuangkan sampah tersebut agar Anif tidak kesulitan. Maksim kedermawanan selanjutnya terdapat pada percakapan Umam dan Anif ketika keduanya hendak membuat kopi. Umam memasak air agar kopi yang hendak dibuat bisa maksimal rasanya, sedangkan Anif berusaha membuat kopi dengan air seadanya. Berikut bentuk tuturannya.

(1) Umam : Diomongi kok, nek banyune ora umup ki ora enak, ki lo tak godokno.

(Diberitahu kok, kalau airnya tidak masak, kopinya tidak enak, ini lo aku masakkan)

(2) Anif : Iyo wes nakno, tak racik e maneh kopine

(Iya sudah, aku racik lagi kopinya).

Penggunaan maksim kedermawanan terdapat pada tuturan (1). Umam berusaha memaksimalkan keuntungan Anif dengan memasak air, sedangkan Anif mendapatkan keuntungan besar dengan usaha Umam.

\subsection{Maksim Penghargaan}

Konteks percakapan Aris dan Umam pada malam hari ketika Aris menyanyikan cuplikan lantunan sholawat, kemudian Umam memujinya. Berikut bentuk tuturannya.

(1) Aris : Assalamualaik zainal anbiya'...

(2) Umam : Suaramu apik nok..

(Suaramu bagus sekali..)

Maksim penghargaan terdapat pada tuturan (2). Umam memaksimalkan pujian kepada Aris yang sedang bernyanyi. Walaupun suara yang dihasilkan biasa saja, tetapi sebagai rasa menghargai antarteman sepantasnya memberi pujian. Maksim penghargaan juga terdapat pada tuturan Arvan dam Umam. Konteks tuturan saat Umam duduk santai di kamar kemudian Arvan datang dan langsung menyicipi kopi yang ada di samping Umam. Berikut bentuk tuturannya.

(1) Arvan : Seger men cah kopine, seng gawe sopo?

(Enak sekali kopinya, yang buat siapa?)

(2) Umam : Gaweane Anif kui mau..

(Kopi buatan Anif ..)

Maksim penghargaan terdapat pada data (2). Arvan memaksimalkan pujian kepada Anif, menganggap bahwa kopi yang Anif buat rasanya enak. Walaupun kopi tersebut rasanya biasa saja, tetapi sebagai rasa menghargai antarteman sepantasnya diberi pujian. Maksim penghargaan selanjutnya terdapat pada percakapan Aris dan Fajar. Konteks tuturannya ketika memulai ngaji, keduanya membuka kitab. Saat itu Aris melirik kitab Fajar, ia kagum dengan 
kitab Fajar yang penuh dengan tulisan pengartian pada tulisan kitabnya. Berikut bentuk tuturannya.

(1) Aris : Weh, kebek temen makna kitabmu?

(Wah, arti dalam kitabmu sudah penuh ya?)

(2) Fajar: La aku budal ngaji terus kok..

(Aku kan berangkat ngaji terus.)

Maksim penghargaan terdapat pada tuturan (1). Sekalipun kitab Fajar masih ada yang belum diartikan, tetapi Aris mengatakan bahwa kitab Fajar sudah penuh dengan catatan pemaknaan. Dengan demikian, Fajar merasa dihargai dengan apa yang ia lakukan.

\subsection{Maksim Kesederhanaan}

Maksim kesederhanaan terdapat pada percakapan antara Fajar dan Umam. Konteks tuturan terjadi pada malam hari ketika Aris mengerjakan tugas kuliah; Fajar lewat sambil melirik laptop yang ada di hadapan Umam. Berikut bentuk tuturannya.

(1) Fajar: Weh, akeh tenan tugasmu, 40 lembar.

(Wah, banyak sekali tugasmu sampai 40 lembar.)

(2) Umam : Iki sitik yo, kancaku enek seng 60 lembar.

(Ini termasuk sedikit, temanku ada yang 60 lembar.)

Penggunaan maksim kesederhanaan terdapat pada tuturan (2). Umam menunjukkan sikap sederhana agar tidak dianggap sombong oleh Fajar. Ia menganggap bahwa tugas yang dikerjakan termasuk sedikit. Contoh lain dari maksim kesederhanaan terdapat pada percakapan Umam dan Wahid. Konteks pada saat acara sholawatan. Umam menyuruh Wahid untuk membaca sholawat. Berikut bentuk tuturannya.

(1) Umam : Engko seng moco kowe ya.

(Nanti yang baca kamu ya.)

(2) Wahid : Ojo aku, suaraku pas-pasan yo.

(Jangan aku, suaraku pas-pasan.)

Maksim kesederhanaan terdapat pada data (2). Wahid meminimalkan keuntungan pada dirinya agar tidak dianggap sombong. Ia menganggap bahwa suaranya pas-pasan. Contoh maksim kesederhanaan yang lain terdapat pada percakapan Anif dan Makruf. Konteks tuturan ketika Anif hendak berangkat kuliah. Saat itu Anif menyemprotkan minyak wangi ke bajunya. Baunya pun sampai tercium oleh makruf, kemudian makruf menanggapinya. Berikut bentuk tuturannya.

(1) Makruf : Minyakmu wangi menNif?

(Minyak kamu harum sekali Nif?)

(2) Anif : Halah, padahal yo podo karo gone cah-cah

(Halah, padahal sama dengan yang teman-teman punya.) 
Penggunaan maksim kesederhanaan terdapat pada tuturan (2). Anif menjelaskan bahwa minyak wangi yang ia miliki sama dengan milik teman-temannya yang lain. Hal ini dilakukan agar Anif tidak dianggap mewah. Selain itu, ia meminimalkan kelebihan dirinya dengan tidak memamerkan bau minyak wangi yang ia pakai.

\subsection{Maksim Permufakatan}

Penggunaan maksim permufakatan terdapat pada percakapan antara santri Aris dan Fajar. Konteks tuturan pada siang hari. Fajar memberikan informasi tentang barang yang di toko, langganan mereka, agar Aris tidak merasa kebingungan ketika ingin mencari peralatan sholat. Nada bicara Fajar terdengar ceria dan santai. Keduanya terdengar akrab dan sudah lama saling kenal. Berikut bentuk tuturannya.

(1) Fajar: "Ehh ris, awakmu ngerti ta nggon biasane dewe tuku kitab?" (kamu tau kan? tempat biasa kita membeli kitab?)

(2) Aris : iyo ngertilah, nang pojok klewer kae t? (iya taulah, di pojok klewer itu kan?)

(3) Fajar: "saiki nang kono enek sorban, sajadah barang e, komplit pokoke (sekarang disana menjual sorban, sajadah, peci, lengkap pokoknya)

Penggunaan maksim pemufakatan terdapata pada tuturan (2). Jawaban tersebut menunjukkan adanya kecocokan maksud yang disampaikan oleh Fajar dan itu menandakan adanya kesamaan informasi toko yang mereka maksudkan sehingga kesepakatan antara keduanya tampak pada jawaban yang diucapkan Aris. Penggunaan maksim kesederhanaan juga terdapat dalam percakapan Umam dan Anif. Keduanya membahas mengenai kopi yang akan mereka beli. Berikut bentuk tuturannya.

(1) Umam : Golek kopi ireng wae yo ben awet? Tak ngajak Wahid. (Cari kopi hitam saja ya.. biar awet? Aku ajak wahid.)

(2) Anif: Yo wes ndang budal kono, tak enteni nang kamar.

(Ya sudah, silahkan berangkat, aku tunggu di kamar.)

Maksim permufakatan terdapat pada tuturan (2). Anif menyetujui ketika Umam hendak mengajak Wahid untuk memilih kopi yang akan dibelinya. Umam dan Anif samasama setuju jika Wahid yang memilih kopinya. Hal tersebut menandakan adanya kesepakatan antara kedua penutur di atas.

\subsection{Maksim Simpati}

Maksim simpati terdapat pada percakapan antara Fata dan Wahid yang terjadi setelah sholat magrib. Konteks tuturan ketika santri lain mulai bergegas untuk mengaji. Fata melihat Wahid yang sedang tidur memakai selimut. Kemudian terjadilah percakapan. Berikut bentuk tuturannya. 
(1) Fata : Kowe ki ngopo kok kemulan ae? (Kamu ini kenapa kok selimutan terus?)

(2) Wahid : Uadem rasane, masuk angin kayake (Dingin sekali rasanya, kelihatannya masuk angin.) Fata : Jajal diombeni tolak angin kono, terus dingo turu. (Coba minum tolak angin, terus dibat tidur.)

Maksim simpati terdapat pada tuturan (3). Fata menganjurkan agar Wahid meminum tolak angin dan tidur agar keadaannya membaik. Perhatian yang diberikan Fata menandakan adanya kepedulian terhadap keadaan Wahid yang merasa kurang sehat badannya. Kepedulian tersebut menandakan adanya maksim simpati dalam percakapan di atas.

Kemudian maksim simpati juga terdapat dalam percakapan antara Rojab dan Makruf. Konteks tuturan terjadi saat iqomah salat Isya' berkumandang, kemudian Rojab dan Makruf hendak menuju masjid untuk menunaikan sholat Isya', tetapi Rojab kehilangan sandalnya. Makruf pun memberi saran kepada Rojab. Berikut bentuk tuturannya.

(1) Rojab : Sandalku ilangteruse.

(Sandalku kok hilang terus ya)

(2) Makruf : Kene lo kekne rak, aman.

(Sini lo, taruh di rak, aman.)

(3) Rojab : Yo wes, engko nek temu tak kekno rakae.

(Ya sudah, nanti kalau ketemu aku taruh rak saja.)

Maksim simpati terdapat pada tuturan (2). Makruf menganjurkan Rojab menaruh sandalnya di rak supaya tidak terus-menerus hilang. Perhatian yang diberikan Makruf menandakan adanya maksim simpati dalam tuturan di atas.

\section{Kesimpulan}

Strategi komunikasi dalam kesantunan berbahasa di lingkungan komunitas santri Pondok Pesantren Al-Hikmah Sukoharjo tidak terhambat oleh adanya perbedaan faktor budaya. Aspek budaya bukan menjadi salah satu penyebab penyimpangan prinsip kesantunan berbahasa. Bahasa yang dipakai dalam komunikasi para santri mengandung prinsip saling menghargai satu sama lain. Hasil kajian ini menunjukkan bahwa dalam proses komunikasi sehari-hari para santri di Pondok Pesantren Al-Hikmah Sukoharjo terdapat adanya penerapan prinsip kesantunan yang di dalamnya mengandung maksim kebijaksanaan, maksim kedermawanan, maksim penghargaan, maksim penghargaan, maksim kesederhanaan, maksim permufakatan, dan maksim simpati. Hal ini terjadi karena mereka memiliki sikap budaya yang saling menghargai meskipun mereka berasal dari kawasan budaya Jawa yang berbeda, yaitu Jawa Timur dan Jawa Tengah. 


\section{Daftar Pustaka}

Chaer, Abdul. 2012. Linguistik Umum. Jakarta: Rineka Cipta.

Fithri, W. 2017. "Kesantunan Permintaan : Interaksi Mahasiswa dan Dosen", dalam Gramatika, 3(1), 9-26.

Rahardi, K. 2005. Pragmatik: Kesantunan Imperatif Berbahasa Indonesia. Yogyakarta: Erlangga.

Rahayu, E. E. 2013. Analisis Kesantunan Berbahasa dalam Interaksi Antarsantri Putri Pondok Pesantren Al-Muayyad Surakarta: Kajian Pragmatik. Surakarta: Universitas Muhammadiyah Surakarta.

Setiawan, H., \& Rois, S. 2017. "Wujud Kesantunan Berbahasa Guru : Studi Kasus di SD Immersion Ponorogo", dalam Jurnal Gramatika, 3(2): 1-12.

Sudaryanto. 1993. Metode dan Aneka Teknik Analisis Bahasa. Yogyakarta: Duta Wacana Univercity Press.

Susilaningtyas, R. D., Wibisono, B., \& Suyanto, B. 2017. "Kesantunan Imperatif pada Masyarakat Madura di Pasar Ikan Desa Kota Kulon, Kabupaten Bondowoso", dalam Semiotika, 18(2): 1-7.

Sutrisni, S. 2005. Alih Kode dan Campur Kode dalam Wacana Interaksi Jual Beli di Pasar Johar, Semarang. Semarang: Universitas Negeri Semarang.

Tarigan, H. G. 1986. Menyimak sebagai Suatu Keterampilan Berbahasa. Bandung: Angkasa.

Yule, G. 2004. Pragmatik. Dierjemahkan oleh Indah Fajar Wahyuni 2006. Yogyakarta: Pustaka Pelajar. 